\title{
Control of thermal regime of thermoelectric coolers in uniform temperature field
}

\author{
Vladimir P. Zaykov ${ }^{1)}$ \\ ORCID: https://orcid.org/ 0000-0002-4078-3519; gradan@i.ua. Scopus Author ID: 57192640250 \\ Vladimir I. Mescheryakov ${ }^{2}$ \\ ORCID: https://orcid.org/0000-0003-0499-827X, E-mail: gradan@ua.fm. Scopus Author ID: 57192640885 \\ Yurii I. Zhuravlov ${ }^{3}$ \\ ORCID: http://orcid.org/0000-0001-7342-1031; ivanovich1zh@gmail.com. Scopus Author ID: 57190425471 \\ ${ }^{1)}$ Research Institute STORM, 27, Tereshkova Str. Odessa, 65076, Ukraine \\ 2) State Environmental University, 15, Lvivska Str. Odessa, 65026, Ukraine \\ 3) National University “Odessa Maritime Academy”, 8, Didrikhson Str. Odessa, 65029, Ukraine
}

\begin{abstract}
The possibility of using a complex of thermoelectric coolers to control the thermal regime of heat-loaded elements of radio electronic equipment, the parameters of which significantly depend on the temperature conditions of operation, is considered. The analysis was carried out for conditions of the same level of cooling of semiconductor elements for typical temperature drops, range of dissipation power, current modes of operation, and geometry of thermoelement legs. It is shown that it is rational to use distributed active cooling systems to ensure the required thermal regime of spatially distributed heat-loaded elements with different dissipation power. To ensure the required thermal conditions, it is proposed to use both individual and group variants of the structure layout: heat-loaded element-thermoelectric cooler-radiator. The developed mathematical models of the relationship between the number of thermoelements and the thermal load, the power consumption with the temperature difference and the operating current are analyzed. Models of the main operational characteristics of coolers that are significant for control systems are presented: the relative failure rate and the time to reach a stationary mode. The results of calculations of the main parameters, reliability indicators and dynamic characteristics for an individual version of the layout of thermoelectric coolers with different dissipation power and current operating modes are presented. The group diagram of the arrangement of the object-cooler with series connection and located on the same heat sink and their comparative analysis is considered. When choosing the current mode, it is necessary to take into account the mutual influence and weight of each of the limiting factors, by varying which, when designing the complex and thermoelectric coolers, it is possible to choose compromise modes of operation.

Keywords: Distributed cooler control; models of dynamics and failure rate; layout options; current modes; temperature difference
\end{abstract}

For citation: Zaykov V. P., Mescheryakov V. I., Zhuravlov Yu.I. Control of thermal regime of thermoelectric coolers in uniform temperature field. Herald of Advanced Information Technology. 2021; Vol. 4 No. 4: 329-340. DOI: https://doi.org/10.15276/hait.04.2021.4

\section{INTRODUCTION}

The process of improving electronic equipment is characterized by an increase in its complexity and layout density, including a stable increase in the degree of integration of the element base. A high packing density is especially typical for specialpurpose equipment, which must have the necessary functionality, high performance and reliability at the lowest possible mass and overall dimensions. A significant part of the consumed power from 40 to $75 \%$, used by the element base, is inevitably converted into heat, causing unacceptable overheating of the elements. In some cases, the required parameters of the elements can be obtained only at relatively low temperatures. Under these

(C) Zaykov V., Mescheryakov V., Zhuravlov Yu., 2021 conditions, technical implementation of effective methods of ensuring thermal conditions is necessary, taking into account the design features of the equipment and operating conditions.

One of the most acceptable ways to ensure the thermal conditions of the elements and components of the equipment is thermoelectric, as the most effective in a wide range of operating temperatures from 140 to $350 \mathrm{~K}$. Thermoelectric cooling devices allow you to control the amount of heat flux by simply changing the magnitude of the operating current. The main advantages of the thermoelectric cooling method over others are high reliability and small overall dimensions of thermoelectric devices, ease of control and speed. These advantages are inherently a consequence of the solid-state nature of such coolers, i.e. absence of moving parts, pumped liquids and gases.

This is an open access article under the CC BY license (http://creativecommons.org/licenses/by/3.0) 


\section{LITERATURE REVIEW}

Systems for ensuring thermal modes of electronic equipment are its integral component, since $40-75 \%$ of the power supply is converted into heat [1]. For onboard equipment, thermoelectric coolers are the most acceptable in terms of weight, dimensions, and performance [2, 3]. Since thermoelectric coolers are designed to increase the reliability of heat-loaded elements, they are subject to increased reliability requirements [4]. Reliability indicators are increased due to the structural organization [5], modification of the functioning of modules [6, 7], and optimal design [8,9]. At the same time, the main disadvantage of thermoelectric coolers is associated with the low efficiency of the thermoelement material [10], the creation of which has been devoted to many studies [11]. At the same time, no significant breakthrough has yet been observed in this area. Therefore, modern design is focused on adapting the achieved parameters of coolers to specific applications, where significant progress has been achieved [12]. Thus, it was possible to increase the performance when using graphene $[13,14]$, due to the thermodynamic analysis of the processes in the module [15], by matching the cooler with an infrared camera [16]. Expansion of the field of application of thermoelectric coolers [17, 18] has led to stricter requirements for systems for providing thermal conditions based on them $[19,20]$. These conditions refer to the most important performance indicators: reliability and dynamic characteristics, which always need to be increased and are in conflict [21, 22],[23]. The problem is aggravated by the fact that when using a thermoelectric cooler in the feedback circuit of the control system, an increase in the dynamic characteristics of the cooler is required, which reduces its reliability [24]. In [25], a method is proposed for increasing the dynamic performance by choosing the material of thermoelements without deteriorating the other parameters of the device. However, the interconnection of the parameters of the cooler constitutes a control problem, to which the work [26] is devoted. The issues of reliability of thermoelectric cooling devices were considered in detail in [27], and the dynamic characteristics and their relationship with reliability indicators in [28]. However, the problems of controlling thermoelectric coolers were practically not considered and were limited exclusively to a stationary mode of operation on one heat-loaded element. Modern equipment has many distributed heat sources that need to be provided with a thermal regime (servers, onboard equipment). The inefficiency of general cooling of such equipment is obvious for systems with limited energy resources. Therefore, the relevance of the development of systems for ensuring thermal conditions, the energy of which adapts to inhomogeneous spatially distributed heat sources, is obvious.

\section{PURPOSE AND OBJECTIVES OF THE RESEARCH}

The aim of the work is to develop a topology of a thermal regime control system for controlling thermoelectric coolers of distributed heat sources with a priority in terms of dynamic and reliability indicators.

To achieve this goal, it is necessary to solve the following tasks:

1. To develop a mathematical model of the functioning of thermoelectric coolers, which provides control of the time to reach a stationary mode and the relative failure rate.

2. Analyze the model in the range of operating temperature drops and standard energy modes of operation to determine the compromise conditions of use.

\section{DISTRIBUTED THERMOELECTRIC COOLER MODEL}

The complexity and relevance of the development of effective means of ensuring the thermal conditions of radio electronic equipment is due to its operation under the influence of many destabilizing factors. Climatic conditions and own heat generation sharply reduce the reliability indicators. To provide the required thermal conditions for a number of spatially dispersed and heat-loaded equipment elements, various designs of complexes of thermoelectric coolers are used [27].

Among the design features of the construction of electronic equipment should be attributed to the dispersed arrangement of heat-dependent elements with different dissipation power. Therefore, to provide the required thermal conditions for a number of dispersed heat-dependent and heat-loaded elements, both individual and group versions of the system layout (heat-loaded element - cooler-radiator) can be used.

To calculate the main parameters, reliability indicators, dynamics of functioning of the complex of thermoelectric coolers (TEC), we use the following relations [27].

The number of thermoelements $\mathrm{n}$ of a singlestage TEC can be determined from the ratio:

$$
n=\frac{Q_{0}}{I_{\max K}^{2} R_{K}\left(2 B_{K}-B_{K}^{2}-\Theta\right)},
$$


where: $Q_{0}$ is the value of the heat load, or the power of the heat release of the cooling object, W;

$I_{\max K}=\frac{\overline{e_{K} T_{0}}}{R_{K}}-$ maximum operating current, A;

$\overline{e_{K}} \quad-$ average value of thermoEMF coefficient of thermoelement leg at the end of the cooling process, $\mathrm{B} / \mathrm{K}$;

$$
R_{K}=\frac{l}{\sigma_{K}^{-} S}-\text { electrical resistance of the }
$$

thermoelement leg at the end of the cooling process, Ohm;

$l$ and $S$ - respectively, the height $l$ and crosssectional area $S$ of the thermoelement leg;

$\bar{\sigma}_{K}-$ average value of thermoelement branch electrical conductivity, $\mathrm{S} / \mathrm{cm}$;

$T_{0}$ - temperature of the heat-absorbing junction, $\mathrm{K}$;

$B_{K}=\frac{I}{I_{\max K}}-$ relative operating current at the end of the cooling process.

$I$ - working current value, A;

$\Theta=\frac{T-T_{0}}{\Delta T_{\max }}-$ relative temperature difference;

$T$ - heat-generating junction temperature, $\mathrm{K}$;

$\Delta T_{\max }=0,5 \bar{Z} T_{0}^{2}-$ maximum temperature drop, $\mathrm{K}$;

$\bar{Z}$ - the average value of the efficiency of the initial thermoelectric materials in the module, $1 / \mathrm{K}$.

The power consumption of the TEC $W_{K}$ can be determined from the expression:

$$
W_{K}=2 n I_{\max K}^{2} R_{K} B_{K}\left(B_{K}+\frac{\Delta T_{\max }}{T_{0}} \Theta\right) ;
$$

Voltage drop $U_{K}$

$$
U_{K}=\frac{W_{K}}{I} .
$$

The coefficient of performance $E$ can be calculated using the formula:

$$
E=\frac{Q_{0}}{W_{K}}
$$

The relative value $\lambda / \lambda_{0}$ of the failure rate can be determined from the expression [27]

$$
\lambda / \lambda_{0}=n B_{K}^{2}(\Theta+C) \frac{\left(B_{K}+\frac{\Delta T_{\max }}{T_{0}} \Theta\right)^{2}}{\left(1+\frac{\Delta T_{\max }}{T_{0}} \Theta\right)^{2}} K_{T},
$$

where: $C=\frac{Q_{0}}{n I_{\max K}^{2} R_{K}}$ is the relative heat load; $K_{T}-$ coefficient of lowered temperatures.

The probability of trouble-free operation $P$ of the TEC can be determined from the expression:

$$
P=\exp [-\lambda t],
$$

where $-t$ is the assigned resource, hour.

The expression for determining the time of reaching the stationary mode of operation $\tau$ can be represented in the form [28]:

$$
\tau=\frac{m_{0} C_{0}+\sum_{i} m_{i} C_{i}}{K\left(1+2 B_{K} \frac{\Delta T_{\max }}{T_{0}}\right)} \ln \frac{\gamma B_{H}\left(2-B_{H}\right)}{2 B_{K}-B_{K}^{2}-\Theta} ;
$$

where: $\gamma=\frac{I_{\max H}^{2} R_{H}}{I_{\max K}^{2} R_{K}}$;

$m_{0} C_{0}-$ product of mass and heat capacity of the object of cooling;

$m_{0} C_{0} \rightarrow 0-$ in the absence of a cooling object;

$\sum_{i} m_{i} C_{i}$ - the total value of the product of the heat capacity and the mass of the constituent structural and technological elements on the heat-absorbing junction of the module at a given $l / S$;

$R_{H}-$ electrical resistance of the thermoelement leg at the beginning of the cooling process, Ohm;

$B_{H}=\frac{I}{I_{\max H}}-$ relative operating current at the beginning of the cooling process, at $\tau=0$;

$I_{\max H}=\frac{\overline{e_{H} T}}{R_{H}}-$ maximum operating current at the beginning of the cooling process, $\mathrm{A}$.

Provided that the currents are equal at the beginning and at the end of the cooling process:

$$
I=B_{K} I_{\max K}=B_{H} I_{\max H} .
$$

\section{ANALYSIS OF THE MODEL OF PROVIDING THERMAL REGIMES}

With an individual version of the layout for each separate heat-loaded element, a TEC of a specific design is used with an individual heat sink. The mode of operation is simultaneous for all elements of the complex. In this case, the dissipated 
power of each heat-loaded element of the equipment is constant in time and is, for example, $Q_{0}=0.5 ; 1.0$; $3.0 ; 5.0 ; 10.0 ; 15 \mathrm{~W}$.

In this case, it is necessary to use a number of power sources to ensure the functioning of various designs of thermoelectric cooling devices.

The results of calculations of the main parameters, reliability indicators and the time to reach a stationary mode of operation with an individual layout, for example, in heat-loaded electronics elements with different dissipation power from $Q_{0}=0.5 \mathrm{~W}$ to $Q_{0}=15 \mathrm{~W}$ and six TECs of various designs at a temperature level of cooling $T_{0}=260 \mathrm{~K}$ thermoelement leg geometry $l / S=4.5$ and for different current operating modes are given in Table 1.

Table 1. The main indicators of the thermoelectric system for ensuring thermal conditions in various operating modes at $T_{0}=260 \mathrm{~K} ; T=300 \mathrm{~K} ; \Delta T=40 \mathrm{~K} ; T_{\mathrm{c}}=295 \mathrm{~K} ; R=4.55 \cdot 10^{-3} \mathrm{OM} ; I_{\max }=11,1 \mathrm{~A}$; $\Delta T_{\max }=79.8 \mathrm{~K} ; \Theta=0.5 ; T-T_{\mathrm{c}}=5 \mathrm{~K}$

\begin{tabular}{|c|c|c|c|c|c|c|c|c|c|c|c|c|c|}
\hline Mode & $B$ & $\begin{array}{l}Q_{0}, \\
\mathrm{~W}\end{array}$ & $\begin{array}{l}n, \\
\text { it. }\end{array}$ & $\begin{array}{l}I, \\
\mathrm{~A}\end{array}$ & $\begin{array}{c}W, \\
\mathrm{~W}\end{array}$ & $\begin{array}{c}U, \\
\mathrm{~V}\end{array}$ & $E$ & $\begin{array}{c}\tau, \\
s\end{array}$ & $\begin{array}{c}\alpha F, \\
\mathrm{~W} / \mathrm{K}\end{array}$ & $\begin{array}{c}N, \\
\mathrm{~W} \cdot \mathrm{s}\end{array}$ & $\lambda / \lambda_{0}$ & $\begin{array}{c}\lambda \cdot 10^{8} \\
1 / \mathrm{h}\end{array}$ & $P$ \\
\hline \multirow{7}{*}{$Q_{0 \max }$} & \multirow{7}{*}{1.0} & 0.5 & 1.8 & \multirow{7}{*}{11.1} & 2.3 & 0.21 & \multirow{7}{*}{0.216} & \multirow{7}{*}{7.6} & 0.56 & 17.7 & 1.84 & 5.52 & 0.99945 \\
\hline & & 1.0 & 3.6 & & 4.6 & 0.42 & & & 1.12 & 35.4 & 3.7 & 11.1 & 0.99889 \\
\hline & & 3.0 & 10.8 & & 13.9 & 1.26 & & & 3.4 & 107.0 & 11.1 & 33.3 & 0.99667 \\
\hline & & 5.0 & 18.0 & & 23.2 & 2.1 & & & 5.6 & 178.6 & 18.5 & 55.5 & 0.99446 \\
\hline & & 10 & 36.0 & & 46.4 & 4.2 & & & 11.3 & 357.3 & 37.0 & 111.0 & 0.98896 \\
\hline & & 15 & 54.0 & & 69.6 & 6.3 & & & 16.9 & 535.9 & 54.2 & 1626 & 0.9839 \\
\hline & & 34.5 & 124 & & 160 & 9.5 & & & 38.9 & 1232 & 126.3 & 379 & 0.9628 \\
\hline \multirow{7}{*}{$(n I)_{\min }$} & \multirow{7}{*}{0.707} & 0.5 & 2.2 & \multirow{7}{*}{7.85} & 1.5 & 0.19 & \multirow{7}{*}{0.336} & \multirow{7}{*}{9.2} & 0.40 & 13.8 & 0.566 & 1.7 & 0.99983 \\
\hline & & 1.0 & 4.4 & & 3.0 & 0.38 & & & 0.80 & 27.6 & 1.13 & 3.4 & 0.99966 \\
\hline & & 3.0 & 13.2 & & 9.0 & 1.14 & & & 2.4 & 82.8 & 3.4 & 10.2 & 0.99898 \\
\hline & & 5.0 & 22.0 & & 15.0 & 1.9 & & & 4.0 & 138 & 5.66 & 17.0 & 0.99830 \\
\hline & & 10 & 44.0 & & 30.0 & 3.8 & & & 8.0 & 276 & 11.3 & 34.0 & 0.99660 \\
\hline & & 15 & 66.0 & & 45.0 & 5.7 & & & 12.0 & 414 & 17.0 & 510 & 0.9949 \\
\hline & & 34.5 & 152 & & 103.5 & 13.1 & & & 27.6 & 952 & 39.0 & 117.2 & 0.9883 \\
\hline \multirow{7}{*}{$\left(n I \lambda / \lambda_{0} \tau\right)_{\min }$} & \multirow{7}{*}{0.53} & 0.5 & 3.2 & \multirow{7}{*}{5.9} & 1.3 & 0.22 & \multirow{7}{*}{0.385} & \multirow{7}{*}{12.0} & 0.36 & 15.6 & 0.25 & 0.75 & 0.999925 \\
\hline & & 1.0 & 6.4 & & 2.6 & 0.44 & & & 0.72 & 31.2 & 0.50 & 1.5 & 0.99985 \\
\hline & & 3.0 & 19.2 & & 7.8 & 1.32 & & & 2.16 & 93.6 & 1.5 & 4.5 & 0.99955 \\
\hline & & 5.0 & 32.0 & & 13,0 & 2,2 & & & 3.6 & 156 & 2.5 & 7.5 & 0.99925 \\
\hline & & 10 & 64.0 & & 26.0 & 4.4 & & & 7.2 & 312 & 5.0 & 15.0 & 0.9985 \\
\hline & & 15 & 96.0 & & 39.0 & 6.6 & & & 10.8 & 468 & 7.5 & 22.5 & 0.99775 \\
\hline & & 34.5 & 221 & & 89.7 & 15.2 & & & 24.8 & 1076 & 17.3 & 51.8 & 0.9948 \\
\hline \multirow{7}{*}{$\left(n I \lambda / \lambda_{0}\right)_{\min }$} & \multirow{7}{*}{0.46} & 0.5 & 4.3 & \multirow{7}{*}{5.1} & 1.35 & 0.27 & \multirow{7}{*}{0.37} & \multirow{7}{*}{14.3} & 0.37 & 19.3 & 0.19 & 0.556 & 0.999944 \\
\hline & & 1.0 & 8.6 & & 2.70 & 0.54 & & & 0.74 & 38.6 & 0.37 & 1.11 & 0.999889 \\
\hline & & 3.0 & 25.8 & & 8.1 & 1.62 & & & 2.22 & 115.8 & 1.11 & 3.33 & 0.99967 \\
\hline & & 5.0 & 43.0 & & 13.5 & 2.7 & & & 3.7 & 193 & 1.85 & 5.55 & 0.999445 \\
\hline & & 10.0 & 86.0 & & 27.0 & 5.4 & & & 7.4 & 386 & 3.7 & 11.1 & 0.99889 \\
\hline & & 15.0 & 129.0 & & 40.5 & 8.1 & & & 11.0 & 579 & 5.55 & 16.7 & 0.99833 \\
\hline & & 34.5 & 296.7 & & 93.2 & 18.6 & & & 25.4 & 1332 & 12.8 & 38.3 & 0.9962 \\
\hline \multirow{7}{*}{$\lambda_{\min }$} & \multirow{7}{*}{0.40} & 0.5 & 6.4 & \multirow{7}{*}{4.4} & 1.60 & 0.36 & \multirow{7}{*}{0.316} & & 0.42 & 28.3 & 0.15 & 0.46 & 0.999954 \\
\hline & & 1.0 & 12.8 & & 3.20 & 0.71 & & & 0.84 & 56.6 & 0.31 & 0.92 & 0.999908 \\
\hline & & 3.0 & 38.4 & & 9.60 & 2.16 & & & 2.52 & 170 & 0.92 & 2.76 & 0.99972 \\
\hline & & 5.0 & 64.0 & & 16.0 & 3.60 & & 17.7 & 4.2 & 283 & 1.55 & 4.65 & 0.99954 \\
\hline & & 10.0 & 128.0 & & 32.0 & 7.2 & & & 8.4 & 566 & 3.1 & 9.3 & 0.99907 \\
\hline & & 15.0 & 192 & & 48.0 & 10.8 & & & 12.6 & 849.6 & 4.65 & 14.0 & 0.9986 \\
\hline & & 34.5 & 442 & & 110.4 & 24.8 & & & 29.0 & 1954 & 10.7 & 32.0 & 0.9968 \\
\hline
\end{tabular}

Source: compiled by the authors 
From the point of view of reliability, it should be noted that if the system consists of - independent elements (TEC), and the probability of failure-free operation of the i-th element is equal $P_{i}(t)$, then the total probability of failure-free operation of the system is [27]:

$$
P_{0}(t)=P_{1}(t) \cdot P_{2}(t) \ldots P_{j}(t) \ldots P_{N}(t)=\prod_{i=1}^{N} P_{i}(t) .
$$

In this case, it is necessary to use auxiliary data to calculate the main parameters, reliability indicators and dynamics of functioning.

With an increase in the relative operating current $\mathrm{B}$ at a given temperature difference $\Delta \mathrm{T}$ and the geometry of the thermoelement legs $1 / \mathrm{S}=4.5$ for different heat loads Q0, which corresponds to the dissipation power of the elements, the number of thermoelements $\mathrm{n}$ decreases (Fig. 1).

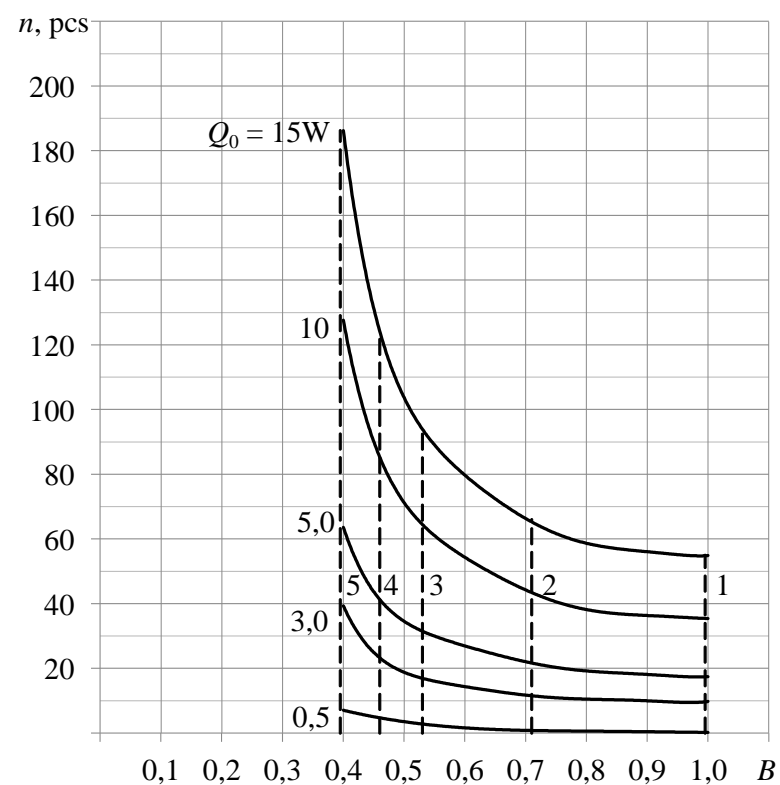

Fig. 1. Dependence of the number of thermoelements $\boldsymbol{n}$ in a single-stage TEC on the relative operating current $B$ for different heat loads $Q_{0}$ at $T=300 \mathrm{~K} ; l / S=4.5 ; \Delta T=40 \mathrm{~K}$ :

$1-Q_{0 \max }$ mode; $2-(n I)_{\min }$ mode; $3-\left(n I / / \lambda_{0} \tau\right)_{\min }$ mode; $4-\left(n I \lambda / \lambda_{0}\right)_{\min }$; 5 - mode $\lambda_{\min }$

Source: compiled by the authors

At a given relative operating current $B$, with an increase in the thermal load $Q_{0}$, the number of thermoelements $n$ increases. The minimum number of thermoelements $\mathrm{n}_{\min }$ is provided in the $\mathrm{Q}_{0 \text { max }}$ mode. and the time of reaching the stationary operating mode $\tau$ decreases (Fig. 2).
The time of reaching the stationary operating mode $\tau$ decreases from the $\lambda_{\min }$ mode to $Q_{0 \max }$.

The minimum time to reach the stationary operating mode $\tau_{\min }=7.6 \mathrm{sec}$ is provided in the $Q_{0 \max }$ mode:

- the value of the operating current $I$ increases (Fig. 2). The value of the operating current I increases from the mode $\lambda_{\min }$ to $Q_{0 \max }$. The minimum value of the operating current $I_{\min }=4.4 \mathrm{~A}$ is provided in the $\lambda$ min mode, and the maximum $-I_{\max }=11.1 \mathrm{~A}$ in the $Q_{0 \max }$ mode;

- the functional dependence of the coefficient of performance $E=f(B)$ has a maximum at $B=0.53$, which corresponds to the mode $\left(\mathrm{nI} \lambda / \lambda_{0} \tau\right)_{\min }$ (Fig. 2);

- the relative failure rate $\lambda / \lambda_{0}$ increases (Fig. 3).

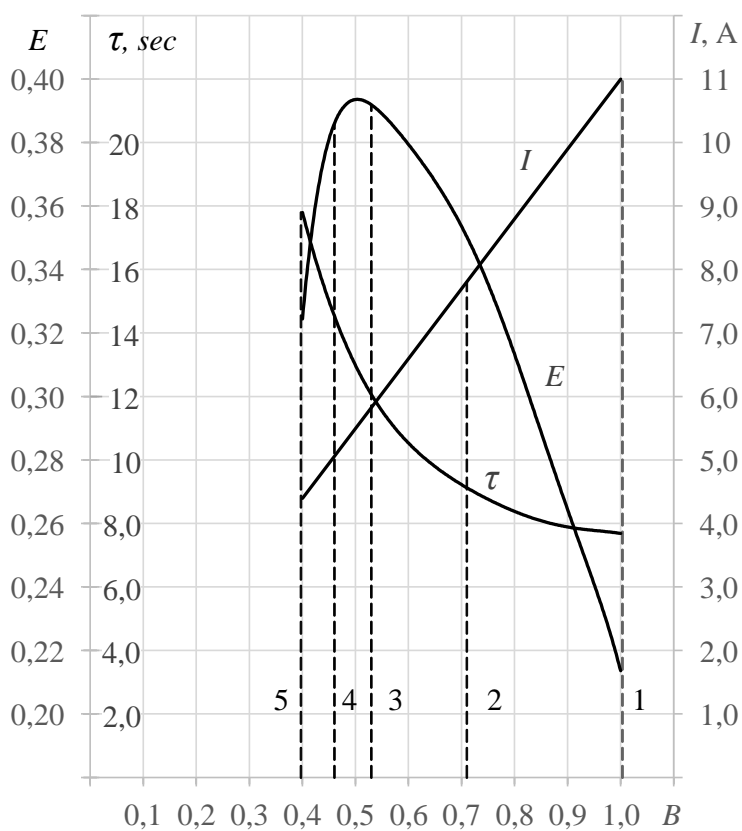

Fig. 2. Dependence of the cooling coefficient $-\boldsymbol{E}$, the time to reach the stationary operating mode $\tau$ and the value of the operating current $-I$ of a single-stage TPP on the relative operating current $B$ at $T=300 \mathrm{~K} ; l / S=4.5 ; \Delta T=40 \mathrm{~K}$ : $1-Q_{0 \max }$ mode; $2-(n I)_{\min }$ mode;

3 - $\left(n I \lambda / \lambda_{0} \tau\right)_{\min }$ mode; 4 - mode $\left(n I \lambda / \lambda_{0}\right)_{\min }$; 5 - mode $\lambda_{\min }$ Source: compiled by the authors

With an increase in the heat load $Q_{0}$, the relative failure rate $\lambda / \lambda_{0}$ increases at a given relative operating current $B$. The relative failure rate $\lambda / \lambda_{0}$ decreases from the $Q_{0 \max }$ mode to the $\lambda_{\min }$ mode. The minimum failure rate $\left(\lambda / \lambda_{0}\right)_{\min }$ is provided in the mode $\left(\lambda / \lambda_{0}\right)_{\min }$;

- the probability of failure-free operation $P$ decreases (Fig. 3). 
For a given relative operating current $B$, with an increase in the thermal load $Q_{0}$, the probability of failure-free operation $P$ decreases. The probability of no-failure operation $P$ increases from the $Q_{0 \max }$ mode to $\lambda_{\min }$.

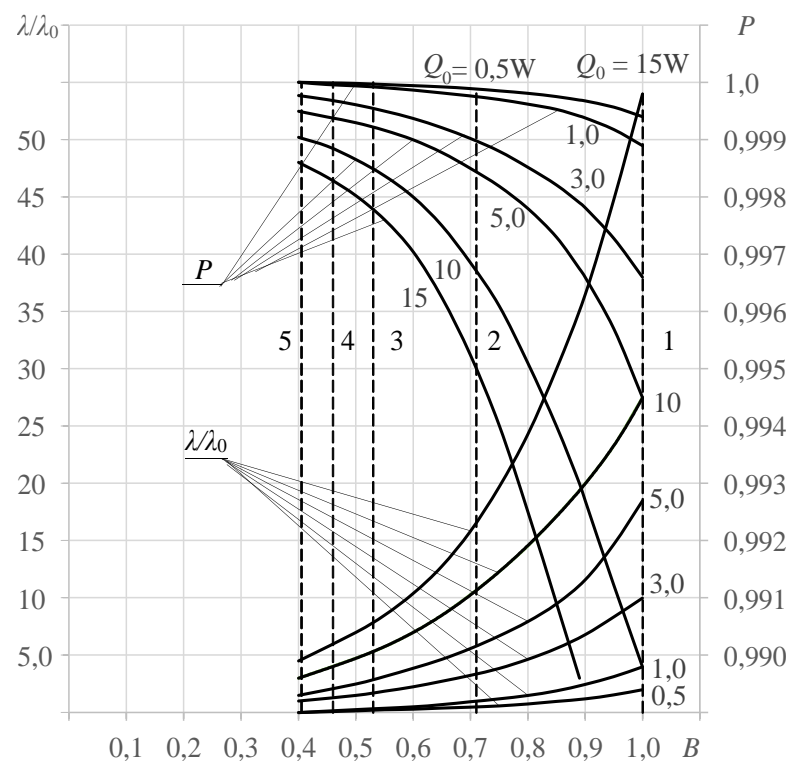

Fig. 3. Dependence of the relative failure rate $\lambda / \lambda_{0}$ and the probability of failure-free operation $P$ of a single-stage TPP on the relative operating current $B$ for different thermal loads $Q_{0}$ at $T=300 \mathrm{~K} ; l / S=4.5 ; \Delta T=40 \mathrm{~K} ; \lambda_{0}=3 \cdot 10^{-8} 1 /$ hour $; t=10^{4}$ hour:

$1-Q_{0 \max }$ mode; $2-(n I)_{\min }$ mode;

$3-\left(n I \lambda / \lambda_{0} \tau\right)_{\min } \operatorname{mode} ; 4-\operatorname{mode}\left(n I \lambda / \lambda_{0}\right)_{\min }$; 5 - mode $\lambda_{\min }$

Source: compiled by the authors

The maximum probability of no-failure operation $P_{\max }$ is provided in the $\lambda_{\min }$ mode:

- the functional dependence of the required heat dissipation capacity of the radiator $\alpha F=f(B)$ has a minimum at $B=0.53$, which corresponds to the mode $\left(n I / / \lambda_{0} \tau\right)_{\min }$ (Fig. 4); With an increase in the heat load $Q_{0}$, the required heat dissipation capacity of the radiator $\alpha F$ increases at a given relative operating current $B$;

- the functional dependence of the amount of consumed energy $N=f(B)$ has a minimum at $B=$ 0.707 (Fig. 5), which corresponds to the mode $(n I)_{\min }$. With an increase in the heat load $Q_{0}$, the amount of consumed energy $N$ increases at a given relative operating current $B$;

- the functional dependence of the voltage drop $U=f(B)$ has a minimum at $B=0.71$, which corresponds to the mode $(n I)_{\min }$ (Fig. 6). With an increase in the thermal load $Q_{0}$, the voltage drop $U$ increases at a given relative operating current $B$.
A variant of the group layout of the system, consisting of 6 heat-loaded elements and 6 coolers (TEC) on one heat sink, is considered.

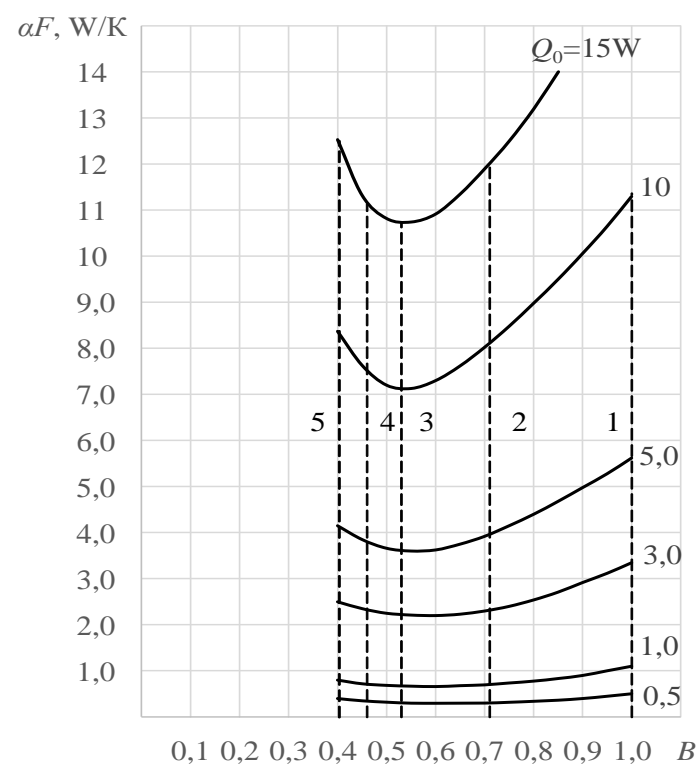

Fig. 4. Dependence of the heat-removing capacity of the radiator $\alpha F$ of a single-stage TEC on the relative operating current $B$ for different heat loads $Q_{0}$ at $T=300 \mathrm{~K} ; l / S=4.5 ; \Delta T=40 \mathrm{~K}$ :

$1-Q_{0 \max }$ mode; $2-(n I)_{\min }$ mode;

$3-\left(n I \lambda / \lambda_{0} \tau\right)_{\min }$ mode; 4 - mode $\left(n I / / \lambda_{0}\right)_{\min }$; 5 - mode $\lambda_{\min }$ Source: compiled by the authors

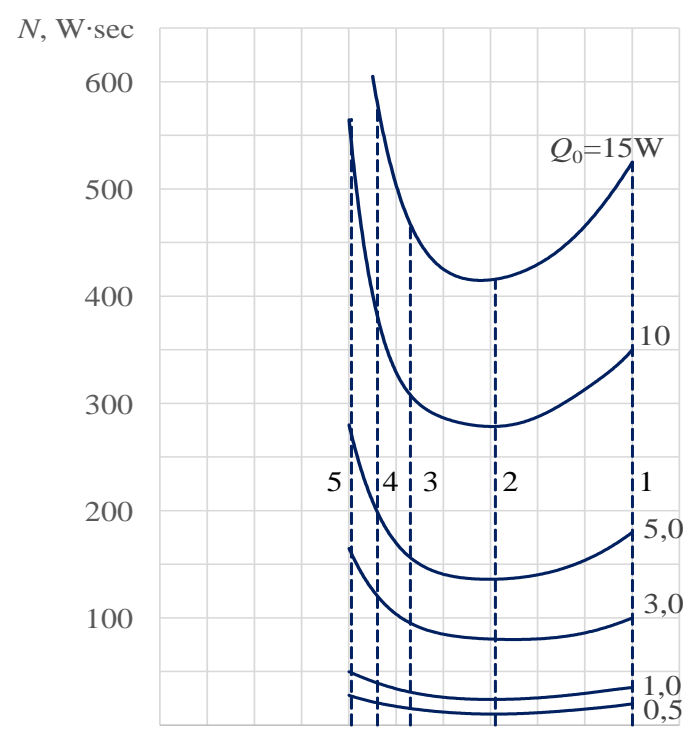

$0,10,20,30,40,50,60,70,80,91,0 \quad B$

Fig.5. Dependence of the amount of consumed energy $N=W \cdot \tau$ of a single-stage TPP on the relative operating current $B$ for different heat loads $Q_{0}$ at $T=300 \mathrm{~K} ; l / S=4.5 ; \Delta T=40 \mathrm{~K}$ :

$1-Q_{0 \max }$ mode; $2-(n I)_{\min }$ mode; $3-\left(n I \lambda / \lambda_{0} \tau\right)_{\min }$ mode; 4 - mode $\left(n I / / \lambda_{0}\right)_{\min }$; 5 - mode $\lambda_{\min }$

Source: compiled by the authors 
In this case, one heat-loaded element is installed on each TEC, and all TECs together with cooling objects are located on one common heat-removing radiator with separate power supply to each TEC.

The results of calculations of the main parameters, reliability indicators and dynamics of functioning with separate power supply (objectcooler) are shown in Table 1. Conditions: temperature level of cooling $T_{0}=260 \mathrm{~K}$, heat load range $Q_{0}=0.5-15 \mathrm{~W}$ for various current operating modes.

A positive point in this layout is the overall heat sink. The disadvantages of this layout option, as with an individual scheme, include the need to use a number of power supplies (see Table 1).

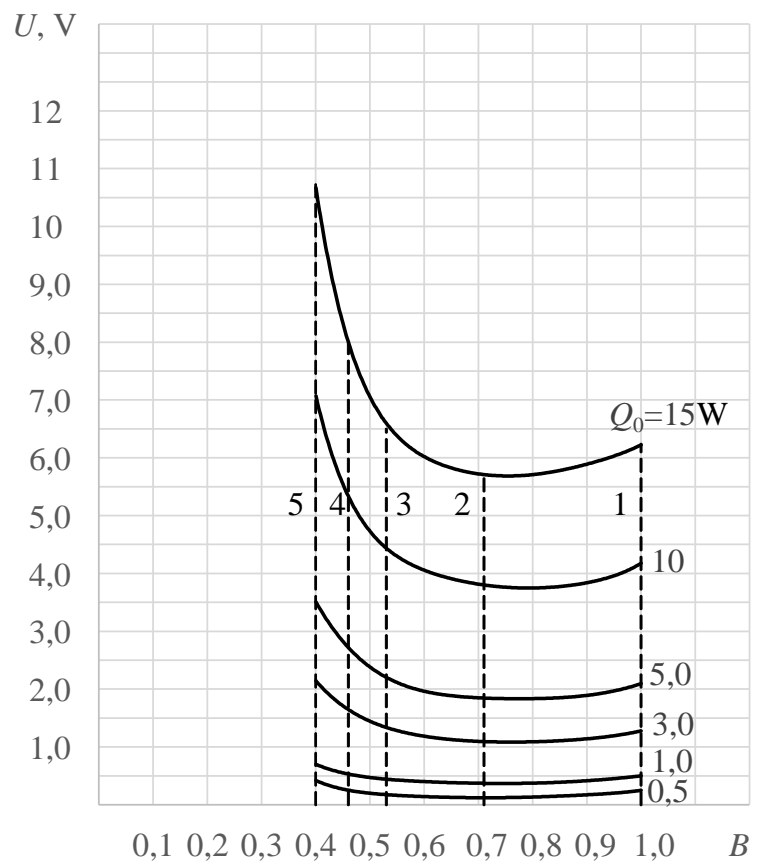

Fig. 6. Dependence of the voltage drop $U$ of a single-stage TPP on the relative operating current $B$ for the different heat loads $Q_{0}$ at $T=300 \mathrm{~K} ; l / S=4.5 ; \Delta T=40$ :

$1-Q_{0 \max }$ mode; $2-(n I)_{\min }$ mode;

$3-\left(n I \lambda / \lambda_{0} \tau\right)_{\min }$ mode; $4-\operatorname{mode}\left(n I \lambda / \lambda_{0}\right)_{\min }$; 5 - mode $\lambda_{\min }$

Source: compiled by the authors

The mode of operation is simultaneous. That is, the simultaneous inclusion of all elements included in the complex. Consider a group layout system (cooler object) with serial electrical connection of coolers in a complex; located on one heat sink.

With serial electrical connection of coolers, the complex provides:

- the same operating current $I$ depending on the selected current operating mode;

- the value of the heat load $Q_{0}$ is provided by the calculated number of thermoelements $-\mathrm{n}$ in the TEC at a given current operating mode;
- total supply voltage of the TEC complex;

- one and the same refrigerating coefficient $E$, and the time of reaching the stationary operating mode $\tau$;

- the ability to use one power source;

- the possibility of using one thermoelectric module with total cooling capacity.

When carrying out a comparative analysis of the calculated data of the main parameters, reliability indicators and the dynamics of the functioning of the TPP complex, consisting of Mmodules, to ensure both for different temperature levels of cooling and the same with a total thermal load for different current operating modes, the following ratios can be used.

The power consumption of the complex $W_{K}$ is equal to the sum of the power consumption of each TEC included in the complex, at a given current operating mode:

$$
W_{K}=\sum_{i=1}^{M} W_{i} .
$$

The number of thermoelements of the complex $n_{K}$ is equal to the sum of thermoelements in the TEC included in the complex, at a given current operating mode:

$$
n_{K}=\sum_{i=1}^{M} n_{i} .
$$

The refrigerating coefficient of the complex $E_{K}$ is equal to the ratio of the total heat load $Q_{0 \Sigma}$ to the power consumption of the complex $W_{K}$ at a given current operating mode:

$$
\mathrm{E}_{\mathrm{K}}=\frac{Q_{0 \Sigma}}{W_{K}} .
$$

The amount of energy expended by the $N_{K}$ complex is equal to the sum of the energy expended by each TEC included in the complex, for a given current operating mode:

$$
N_{K}=\sum_{i=1}^{M} N_{i} .
$$

The time of reaching the stationary mode of operation of the TEC complex $\tau_{K}$ is equal to the maximum time of reaching the stationary mode of operation of the TPP included in the complex, at a given current operating mode:

$$
\tau_{K}=\tau_{\max T E C} .
$$

When determining the reliability indicators of the TEC complex under operating conditions, namely, the relative failure rate $\lambda / \lambda_{0}$ and the probability of failure-free operation $P$, we assume 
that, firstly, all $\mathrm{n}$ terminals in the TEC are electrically connected in series, the failure of any thermoelement leads to failure building the TEC and the complex as a whole. Events involving the failure of thermoelements are taken independently.

Under the assumptions made, the reliability indicator of the TEC complex $P_{K}(t)$ can be represented as the product of the reliability of the TEC $P_{i}(t)$ :

$$
\left.\left.P_{K}(t)=\prod_{i=1}^{M} P_{i}\right) t\right),
$$

or taking into account the fact that the value of reliability of the i-th TEC during time $t$ is determined by the expression:

$$
P(t)=\exp \left[-\int_{0}^{t} \lambda(t) d t\right]
$$

Then the expression for determining the reliability of the TPU complex will take the form:

$$
P_{K}(t)=\exp \left[-\sum \lambda_{i}(t) d t\right] .
$$

With a serial electrical connection of the TEC in the complex, the total voltage drop of the $U_{K}$ complex is equal to the sum of the voltage drops on the TEC included in the complex, at a given current operating mode:

$$
U_{K}=\sum_{i=1}^{M} U_{i} .
$$

The required heat dissipation capacity of the radiator of the TEC $\alpha F_{K}$ complex is equal to the sum of the heat removal capabilities of the TEC radiators included in the complex, at a given current operating mode:

$$
\alpha F_{K}=\sum_{i=1}^{M} \alpha F_{i}
$$

The value of the operating current I of the TEC complex with a serial electrical connection can be determined from the ratio for a given current operating mode:

$$
I_{K}=\frac{W_{K}}{U_{K}} .
$$

The results of calculations of the main parameters, reliability indicators and the time to reach a stationary mode of operation for a group layout (cooling object) of a complex with a series electrical connection of coolers are shown in Table 2.

\section{DISCUSSION OF RESEARCH RESULTS}

With an increase in the relative operating current $B$ of the complex at a given temperature drop $\Delta T=40 \mathrm{~K}$ and heat load $Q_{0}=34.5 \mathrm{~W}$ and the geometry of thermoelement legs $l / S=4.5$ :

- the value of the operating current $I$ (Fig. 2) increases from $I_{\min }=4.4 \mathrm{~A}$ in the mode $\lambda_{\min }$ to $I_{\max }=$ $11.1 \mathrm{~A}$ in the mode $Q_{0 \max }$;

- the time of reaching the stationary operating mode $\tau$ decreases (Fig. 2).

The minimum time to reach the stationary operating mode $\tau_{\min }=7.7 \mathrm{sec}$ is provided in the $Q_{0 \max }$ mode.

- the number of thermoelements $\mathrm{n}$ decreases (Fig. 7).

The minimum number of thermoelements nmin $=124$ pcs is provided in the Q0max mode:

- the functional dependence of the voltage drop $U=f(B)$ has a minimum at $B=0.707$ in the $(n I)_{\min }$ mode (Fig. 7), $U_{\min }=13.1 \mathrm{~V}$;

- the functional dependence of the coefficient

\begin{tabular}{|c|c|c|c|c|c|c|c|c|c|c|c|c|}
\hline Mode & $B$ & $\begin{array}{l}I, \\
\mathrm{~A}\end{array}$ & $\begin{array}{l}n, \\
\text { it. }\end{array}$ & $\begin{array}{l}W \\
\mathrm{~W}\end{array}$ & $\begin{array}{l}U, \\
\mathrm{~V}\end{array}$ & $E$ & $\begin{array}{l}\tau, \\
\mathrm{s}\end{array}$ & $\begin{array}{c}\alpha F, \\
\mathrm{~W} / \mathrm{K}\end{array}$ & $\begin{array}{c}N, \\
\mathrm{~W} \cdot \mathrm{s}\end{array}$ & $\lambda / \lambda_{0}$ & $\begin{array}{c}\lambda \cdot 10^{8} \\
1 / \mathrm{h}\end{array}$ & $P$ \\
\hline$Q_{0 \max }$ & 1.0 & 11.1 & 124 & 160 & 14.5 & 0.216 & 7.7 & 39.0 & 1232 & 126.3 & 379.0 & 0.9628 \\
\hline$(n I)_{\min }$ & 0.707 & 7.85 & 152 & 104 & 13.1 & 0.336 & 9.2 & 27.6 & 956.8 & 39.0 & 117.2 & 0.9883 \\
\hline$\left(n I \lambda / \lambda_{0} \tau\right)_{\min }$ & 0.53 & 5.9 & 221 & 90.0 & 15.2 & 0.385 & 12.0 & 24.8 & 1080 & 17.3 & 51.8 & 0.9948 \\
\hline$\left(n I \lambda / \lambda_{0}\right)_{\min }$ & 0.46 & 5.1 & 297 & 93 & 18.6 & 0.37 & 14.3 & 25.4 & 133 & 12.8 & 38.3 & 0.9962 \\
\hline$\lambda_{\min }$ & 0.40 & 4.4 & 442 & 110 & 24.8 & 0.316 & 17.7 & 29.0 & 1947 & 10.7 & 32.0 & 0.99680 \\
\hline
\end{tabular}
of performance $E=f(B)$ has a maximum at $B=$ 0.53 , which corresponds to the mode $(n I \lambda / \lambda 0 \tau)_{\text {min }}$. $\mathrm{E}_{\max }=0.385$ (Fig. 2).

Table 2. Main parameters, indicators of reliability and time to reach steady-state mode in the group version of the layout of thermoelectric coolers 


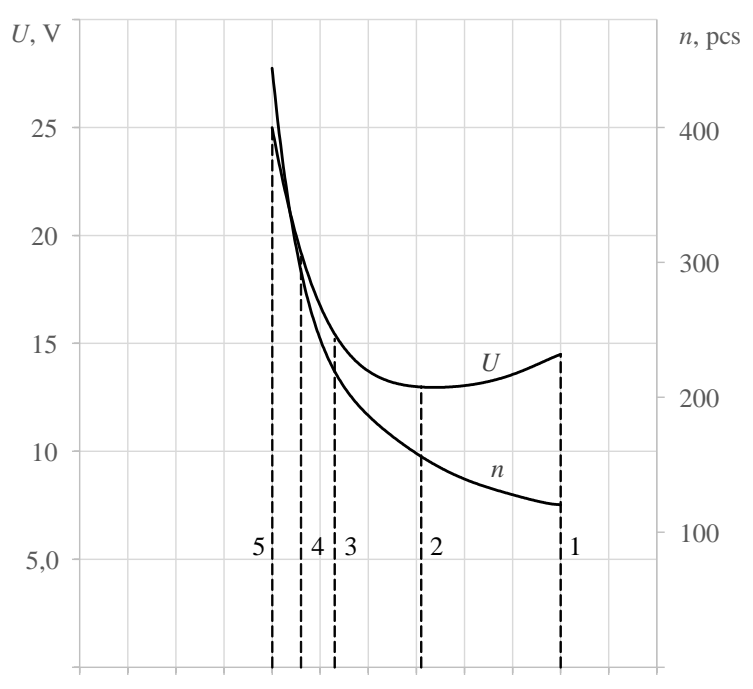

$\begin{array}{lllllllllll}0,1 & 0,2 & 0,3 & 0,4 & 0,5 & 0,6 & 0,7 & 0,8 & 0,9 & 1,0 & B\end{array}$

Fig. 7. Dependence of the number of thermoelements $n$ and the voltage drop $U$ of the TPP complex with their serial electrical connection on the relative operating current $B$ at $T_{\mathrm{c}}=300 \mathrm{~K} ; \Delta T=40 \mathrm{~K} ; l / S=4.5$ :

$1-Q_{0 \max }$ mode; 2 - $(n I)_{\min }$ mode;

$3-\left(n I / / \lambda_{0} \tau\right)_{\min } \operatorname{mode} ; 4-\operatorname{mode}\left(n I \lambda / \lambda_{0}\right)_{\min }$; 5 - mode $\lambda_{\text {min }}$

Source: compiled by the authors

The minimum number of thermoelements $n_{\min }=$ 124 pcs is provided in the $Q_{0 \max }$ mode:

- the functional dependence of the voltage drop $U=f(B)$ has a minimum at $B=0.707$ in the $(n I)_{\text {min }}$ mode (Fig. 7), $U_{\min }=13.1 \mathrm{~V}$;

- the functional dependence of the required heat dissipation capacity of the radiator $\alpha F=f(B)$ has a minimum at $B=0.53 \alpha F_{\min }=24.8 \mathrm{~W} / \mathrm{K}$, which corresponds to the mode $(n I \lambda / \lambda 0 \tau)_{\min }$ (Fig. 8);

- the functional dependence of the amount of consumed energy $N=f(B)$ has a minimum at $B=$ $0.71 N_{\min }=957 \mathrm{~W} / \mathrm{s}$, which corresponds to the mode (nI min (Fig. 8);

- the relative failure rate $\lambda / \lambda 0$ increases and the probability of failure-free operation $\mathrm{P}$ decreases (Fig. 9).

Thus, the criterion for choosing the current mode of operation can be both one- and multifactorial. In most cases, it is necessary to consider the mutual influence and weight of each of the limiting factors. Since the conditions for the design of the TEC complex to ensure the thermal regime of a number of dispersed elements can be very diverse. By varying simultaneously several limiting factors $\left(n, I, E, \lambda / \lambda_{0}, \tau\right)$, one can choose compromise modes of operation.

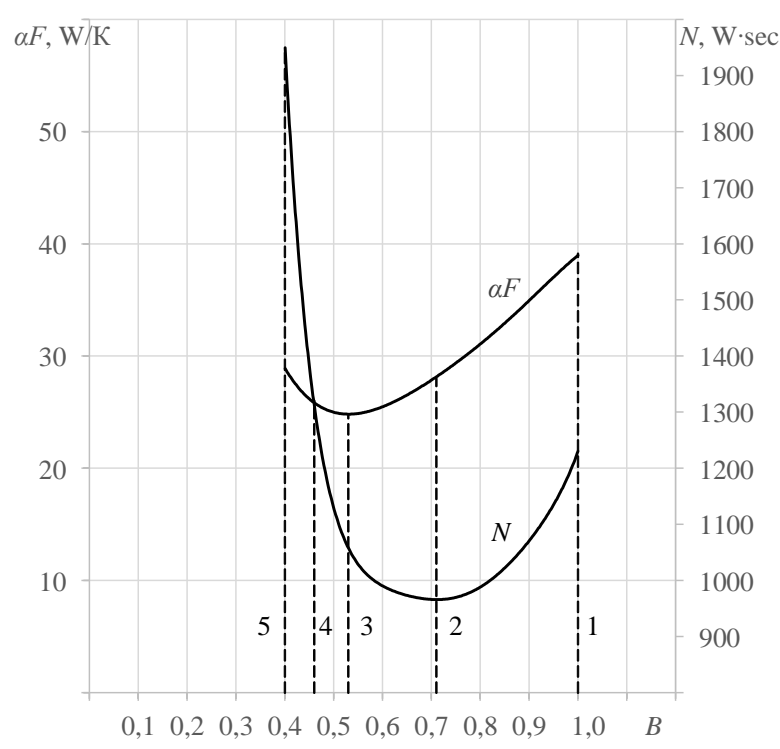

Fig. 8. Dependence of the $\boldsymbol{N}, \boldsymbol{\alpha F}$ values of the TPP complex with their serial electrical connection on the relative operating current $B$ at $T_{\mathrm{c}}=300 \mathrm{~K}$; $\Delta T=40 \mathrm{~K} ; l \mid / S=4.5$ :

$1-Q_{0 \max }$ mode; 2 - $(n I)_{\min }$ mode; $3-\left(n I \lambda / \lambda_{0} \tau\right)_{\min } \operatorname{mode} ; 4-\operatorname{mode}\left(n I \lambda / \lambda_{0}\right)_{\min }$; 5 - mode $\lambda_{\min }$ Source: compiled by the authors

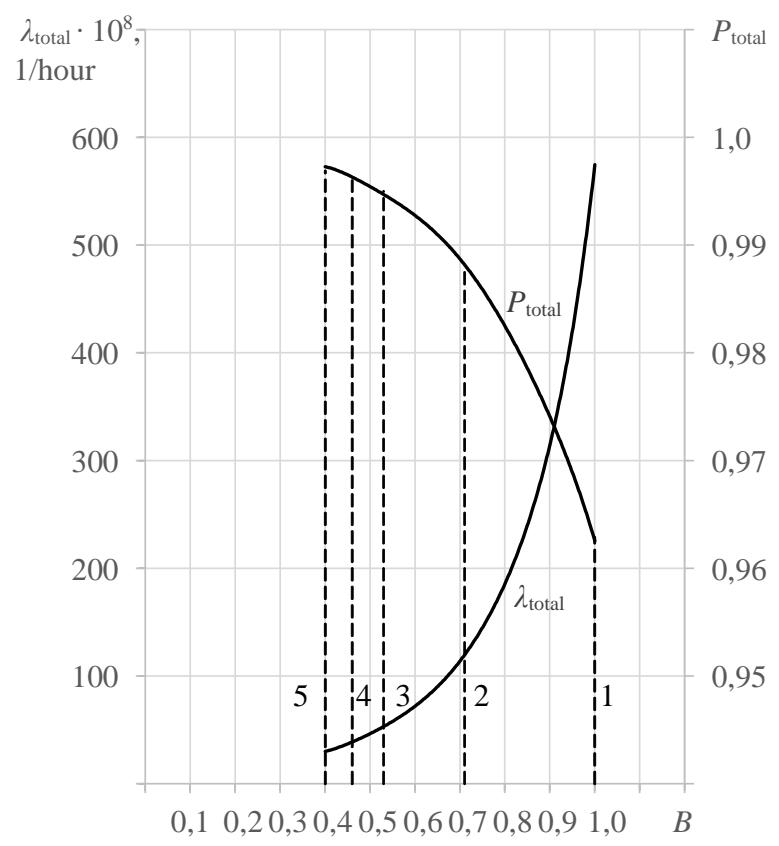

Fig. 9. Dependence of the failure rate $\lambda_{\text {total }}$ and the probability of failure-free operation $\boldsymbol{P}_{\text {total }}$ of the TPP complex on the relative operating current $B$ at $T=300 \mathrm{~K} ; \Delta T=T=40 \mathrm{~K} ; Q_{0}=0.5 ; \div 15.0 \mathrm{~W}$;

$T-T_{\mathrm{c}}=5 \mathrm{~K} ; \lambda_{0}=3 \cdot 10^{-8} 1 /$ hour; $\mathrm{t}=10^{4}$ hour:

$1-Q_{0 \max }$ mode; $2-(n I)_{\min }$ mode;

$3-\left(n I / / \lambda_{0} \tau\right)_{\min }$ mode; $4-\operatorname{mode}\left(n I \lambda / \lambda_{0}\right)_{\min }$; 5 - mode $\lambda_{\min }$

Source: compiled by the authors 


\section{CONCLUSIONS}

1. A mathematical model of a thermoelectric cooler has been developed, which connects the energy and design parameters with the dynamics and reliability indicators of the device, which makes it possible to determine a compromise between competing characteristics already at the design stage.

2. The analysis of the model has been carried out and the conditions for obtaining the extrema of the required energy, heat-removing capacity of the radiator, and the coefficient of performance, which are significant for on-board systems, have been identified.

3. Variants of the structures of systems for ensuring temperature regimes of heat-loaded equipment are proposed, the control system of which is based on taking into account the extreme values of energy and design indicators, their comparative analysis is carried out.

\section{REFERENCES}

1. Gordon N. Ellison. "Thermal Computations for electronics. conductive, radiative, and convective air cooling". CRC Press. Boca Raton. 2020. 404 p. DOI: https://doi.org/10.1201/9781003029328.

2. Sulaiman, A. C., Amin, N. A. M., Basha, M. H., Majid, M. S. A., Nasir, N. F. b. M. \& Zaman, I. "Cooling performance of thermoelectric cooling (tec) and applications: a review". MATEC Web Conf. 2018; Vol. 225. DOI: https://doi.org/10.1051/matecconf/201822503021.

3. Bakhtiaryfard, L. \& Chen, Y. S. "Design and analysis of a thermoelectric module to improve the operational life". Advances in Mechanical Engineering. 2014; 7(1). DOI: https://doi.org/10.1155/2014/152419.

4. Choi, H.-S., Seo, W.-S. \& Choi, D.-K. "Prediction of reliability on thermoelectric module through accelerated life test and physics-of-failure", https://www.researchgate.net/journal/17388090_Electronic_Materials_Letters. 2011. DOI: https://doi.org/10.1007/s13391-011-0917-x.

5. Erturun, U. \& Mossi, K. "A feasibility investigation on improving structural integrity of thermoelectric modules with varying geometry". 2012. DOI: https://doi.org/10.1115/SMASIS2012-8247.

6. Manikandan, S., Kaushik, S. C. \& Yang, Ronggui. "Modified pulse operation of thermoelectric coolers for building cooling applications". Energy Conversion and Management. 2017; 140: 145-156. DOI: https://doi.org/10.1016/j.enconman.2017.03.003.

7. Venkatesan, K. \& Venkataramanan, M. "Experimental and simulation studies on thermoelectric cooler: a performance study approach". International Journal of Thermophilic. 41. Epub ahead of print 2020. DOI: https://doi.org/10.1007/s10765-020-2613-2.

8. Li, H., Meng, F. \& Jing, D. "Optimal design and thermal modelling for liquid-cooled heat sink based on multi-objective topology optimization: An experimental and numerical study". International Journal of Heat and Mass Transfer. 2019; 144: 1-18. DOI: https://doi.org/10.1016/j.ijheatmasstransfer.2019.118638.

9. Dong, X. \& Liu, X. "Multi-objective optimal design of microchannel cooling heat sink using topology optimization method". International Journal of Computation and Methodology. 2020; Vol. 77. DOI: https://doi.org/10.1080/10407782.2019.1682872.

10. Sootsman, J. R., Chung, D. Y. \& Kanatzidis, M. G. "New and old concepts in thermoelectric materials". Angewandte Chemie International Edition. 2009; 48 (46): 8616-8639. DOI: https://doi.org/10.1002/anie.200900598.

11. Jin, W., Liu, L., Yang, T., Shen, H., Zhu, J., Xu, W., Li, S., Li, Q., Chi, L., Di, C.\& Zhu, D. "Exploring Peltier effect in organic thermoelectric films". Nat Commun. 2018; 9: 3586. DOI: https://doi.org/10.1038/s41467-018-05999-4.

12. Ebale, L. O., Pierre Gomat, L. J., Nzonzolo, L., Mavoungou, M. R. \& Kibongani, F. "Optimization of a thermoelectric cooling system with Peltier effect". Am. J. Energ. Eng. 2019; 7 (3): 55-63. DOI: https://doi.org/10.11648/j.sjee.20190703.12.

13. Duan, J., Wang, X., Lai, X., Li, G., Watanabe, K. \& Taniguchi, T. "High thermoelectricpower factor in graphene/hBN devices". Proc Natl Acad Sci USA, 2016; 113 (50): 14272-14276. DOI: https://doi.org/10.1073/pnas.1615913113.

14. Hu, J.-Z., Liu, B., Zhou, J., Li, B. \& Wang, Y. "Enhanced thermoelectric cooling performance with graded thermoelectric materials". Jpn. J. Appl. Phys. 2018; 57, 071801. DOI: https://doi.org/10.7567/jjap.57.071801.

15. Eslami, M., Tajeddini, F. \& Etaati, N. "Thermodynamic analysis and optimization of water harvesting from air using thermoelectric coolers". Journal Energy Conversion and Management, https://www.researchgate.net/publication/327120843. 2018; Vol. 174: 417-429. 
16. Wang, L. Q., Zhou, L. \& Fan, H. T. "Design of cooling system for infrared CCD camera used to monitor burden surface of blast furnace based on thermoelectric coolers". Applied Mechanics and Materials. 2013; Vol. 419: 778-783. DOI: https://doi.org/10.4028/www.scientific.net/AMM.419.778.

17. Yu, J., Zhu, Q., Kong, L., Wang, H. \& Zhu, H. "Modeling of an integrated thermoelectric generation-cooling system for thermoelectric cooler waste heat recovery". Energies. 2020; 13(18). DOI: https://doi.org/10.3390/en13184691.

18. Irshad, K., Almalawi, A., Khan, A. I., Alam, Md M., Zahir, Md. H \& Ali, A. "An IoT-based thermoelectric air management framework for smart building applications: a case study for tropical climate". Sustainability. 2020; Vol. 12 (4): 1-18. DOI: https://doi.org/10.3390/su12041564.

19. Cai, Y., Wang, Y., Liu, D. \& Zhao, F.-Y. "Thermoelectric cooling technology applied in the field of electronic devices: updated review on the parametric investigations and model developments". Appl. Therm. Eng. 2019; 148: 238-255. DOI: https://doi.org/10.1016/j.applthermaleng.2018.11.014.

20. Ngo, T.-T., Wang, C.-C., Chen, Y.-T. \& Than, V.-T. "Developing a thermoelectric cooling module for control temperature and thermal displacement of small built-in spindle". Therm. Sci. Eng. Prog. 2021. 25. DOI: https://doi.org/10.1016/j.tsep.2021.100958.

21. Saifizi, M., Lee, T. W., Anuar, S. N. N., Zunaidi, I., Diana, N. S., Mustafa, W. A., et al. "Development and investigation of thermoelectric cooling performance based on space scales". IOP Conf. Ser. Mater. Sci. Eng. 2018; 429. DOI: https://doi.org/10.1088/1757-899x/429/1/012083.

22. Weerasinghe, R. \& Hughes, T. "Numerical and experimental investigation of thermoelectric cooling in down-hole measuring tools; a case study". Case Stud. Therm. Eng. 2017; 10: 44-53. DOI: https://doi.org/10.1016/j.csite.2017.02.002.

23. You, L., Mohammad Siddique, A. R., Andrew Gadsden, S. \& Mahmud, S. "Experimental investigation of thermoelectric cooling for a new battery pack design in a copper holder". Results Eng. 2021; 10. DOI: https://doi.org/10.1016/j.rineng.2021.100214.

24. Zaykov, V., Mescheryakov, V. \& Zhuravlov, Y. "Analysis of relationship between the dynamics of a thermoelectric cooler and its design and modes of operation". Eastern-European Journal of Enterprise Technologies, 2018; Vol. 1 No. 8 (91): 12-24. DOI: https://doi.org/10.15587/1729-4061.2018.123891.

25. Zaykov, V., Mescheryakov, V. \& Zhuravlov, Yu. "Studying the influence of the thermoelectric materials parameters on the dynamics of singlecascade cooling devices". Eastern-European Journal of Enterprise Technologies. 2020; No. 8(103): 6-18. DOI: https://doi.org/10.15587/1729-4061.2020.195730.

26. Zaykov, V., Mescheryakov, V. \& Zhuravlov, Yu. "Designing a singlecascade thermoelectric cooler with the predefined time to enter a stationary mode of operation". Eastern-European Journal of Enterprise Technologies. 2019; No. 8 (102): 38-46. DOI: https://doi.org/10.15587/1729-4061.2019.184400.

27. Zaykov, V. P., Kinshova, L. A. \& Moiseev, V. F. "Prediction of reliability indicators, thermoelectric cooling devices. Book 1. One-stage devices". Publ. Polytehperiodika. Odessa: Ukraine. 2009. 120 p.

28. Zaykov, V., Mescheryakov, V. \& Zhuravlov, Yu. "Prediction of reliability indicators, thermoelectric cooling devices. Book 4. Dynamics of functioning of single-stage TED”. Publ. Polytehperiodika. Odessa: Ukraine 2019. 290 p.

Conflicts of Interest: the authors declare no conflict of interest

Received $\quad 12.12 .2020$

Received after revision 22.02.2021

Accepted 15.032021

DOI: https://doi.org/10.15276/hait.04.2021.4

УДК 004.662.99·519.6

\title{
Управління тепловим режимом термоелектричних охолоджувачів у рівномірному полі температур
}

\author{
Володимир Петрович Зайков ${ }^{1)}$ \\ ORCID: http://orcid.org/0000-0002-4078-3519; gradan@i.ua. Scopus Author ID: 57192640250 \\ Володимир Іванович Мещеряков ${ }^{2)}$ \\ ORCID: http://orcid.org/ 0000-0003-0499-827X; gradan@ua.fm. Scopus Author ID: 57192640885
}

Юрій Іванович Журавльов ${ }^{3}$

ORCID: http://orcid.org/0000-0001-7342-1031; ivanovich1zh@ gmail.com. Scopus Author ID: 57190425471

1) Науково-дослідницький інститут ШТОРМ, вул. Терешкової 27. Одеса, 65076, Україна

2) Одеський державний екологічний університет, вул. Львівська, 15. Одеса, 65026, Україна

3) Національний університет «Одеська морська академія», вул. Дідріхсона, 8. Одеса, 65029, Україна 


\begin{abstract}
АНОТАЦІЯ
Розглянута можливість використання комплексу термоелектричних охолоджувачів для забезпечення управління тепловим режимом тепло навантажених елементів радіо електронної апаратури, параметри якої суттєво залежать від температурних умов експлуатації. Аналіз проведено для умов однакового рівня охолодження напівпровідникових елементів для типових перепадів температур, діапазону потужності розсіювання, струмових режимів роботи та геометрії гілок термоелементів. Показано, що для забезпечення необхідного теплового режиму просторово розподілених тепло навантажених елементі 3 різною потужністю розсіювання раціонально використовувати розподілені системи активного охолодження. Для забезпечення необхідного теплового режиму запропоновано використовувати як індивідуальний, так $\mathrm{i}$ груповий варіант компонування структури: тепло навантажений елемент-термоелектричний охолоджувач-радіатор. Проаналізовано розроблені математичні моделі зв'язку кількості термоелементів з тепловим навантаженням, споживаної потужності з перепадом температур та робочим струмом. Представлені моделі основних експлуатаційних характеристик охолоджувачів, значущі для систем управління: відносної інтенсивності відмов та часу виходу на стаціонарний режим. Наведено результати розрахунків основних параметрів, показників надійності та динамічних характеристик при індивідуальному варіанті компонування термоелектричних охолоджувачів з різною потужністю розсіювання та струмових режимах роботи. Розглянуто групову схему компонування об'єкта-охолоджувача при послідовному з'єднанні та розташованих на одному тепловідвідному радіаторі та їх порівняльний аналіз. При виборі струмового режиму необхідно враховувати взаємний вплив та вагомість кожного з обмежувальних факторів, варіюючи якими при проектуванні комплексу та термоелектричних охолоджувачів можна вибрати компромісні режими роботи.
\end{abstract}

Ключові слова: управління розподіленими охолоджувачам; моделі динаміки та інтенсивності відмов; варіанти компонування; токові режими; перепад температур

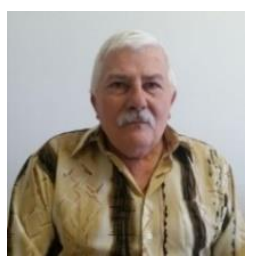

Vladimir P. Zaykov - Candidate of Engineerin
27, Tereshkova Str. Odessa, 65076, Ukraine

ORCID: http://orcid.org/0000-0002-4078-3519; gradan@i.ua. Scopus Author ID: 57192640250

Research field: Reliability and dynamic descriptions of thermo-electric cooling devices; design, planning of the systems of providing of the thermal modes of electronic apparatus

Володимир Петрович Зайков - кандидат технічних наук (1990), начальник сектору Науково - дослідного інституту «ШТОРМ», вул. Терешкової 27. Одеса, 65076, Україна

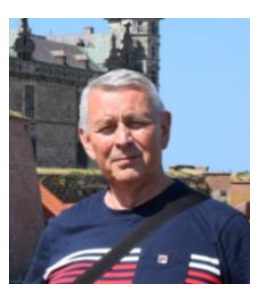

Vladimir I. Mescheryakov, D.Sc. (Eng), Professor, Head of Department of Informatics. State Environmental University. 15, Lvivska Str. Odessa, 65026, Ukraine.

ORCID: http://orcid.org/0000-0003-0499-827X; gradan@ua.fm. Scopus Author ID: 57192640885

Research field: Reliability and dynamic descriptions of thermo-electric cooling devices; design of power processes; biotechnical informative systems

Володимир Іванович Мещеряков - доктор технічних наук, зав. кафедри Інформатики Одеського державного екологічного університету, вул. Львівська, 15. Одеса, 65026, Україна

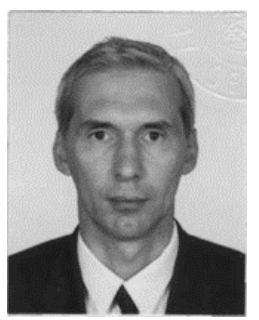

Yurii I. Zhuravlov - Candidate of Engineering Sciences, Associate Professor Department of Technology of Materials and Ship Repair. National University “Odessa Maritime Academy”, 8, Didrikhson Str. Odessa, 65029, Ukraine Odessa, 65029, Ukraine

ORCID: http://orcid.org/0000-0001-7342-1031; ivanovich1zh@gmail.com. Scopus Author ID: 57190425471

Research field: Reliability and dynamic descriptions of thermo-electric cooling devices; reliability and reparability of ship equipment

Юрій Іванович Журавльов - кандидат технічних наук, доцент кафедри Технології матеріалів і судноремонту

Національного університету “Одеська морська академія”, вул. Дідріхсона, 8, Одеса, 65029, Україна 